КОМП'ЮТЕРЕЗАЦІЯ ОСВІТИ МАЙБУТНІХ ФАХІВЦІВ ДЛЯ СФЕРИ ЦИВІЛЬНОГО ЗАХИСТУ В УМОВАХ ПОСТІНДУСТРІАЛЬНОГО СУСПІЛЬСТВА

\title{
COMPUTERIZATION OF THE EDUCATION OF FUTURE CIVIL PROTECTION IN SPECIALISTS THE CONDITIONS OF THE POST-INDUSTRIAL SOCIETY
}

\begin{abstract}
у статті висвітлено питання важливості застосування інфрормаційних технологій майбутніми орахівцями цивільного захисту у професійній діяльності. Від майбутнього фрахівця цивільного захисту вимагається: «грамотний» рівень володіння іноземною мовою, комп'ютерна грамотність, оперативне рішення проблем під час виконання професійних обов'язків, гнучке та інноваційне мислення, схильність і здібність до безперервної освіти. Тому використання сучасних інфрормаційно-комунікаційних технологій в освітній системі навчання та виховання кадрів для ДСНС України є одним із пріоритетних напрямів підготовки та розвитку майбутнього фрахівия цивільного захисту. Фахівці зі сфрери цивільного захисту часто змушені діяти в умовах невизначеності й браку часу. Тож тут украй необхідна активна участь відповідних служб, залучення різних сил і засобів, їх взаємодія. Представлено класифрікацію НС за: причинами виникнення (стихійні, техногенні, антропогенні, змішані); комплексністю й важкістю наслідків (кризові, катастрофрічні, надзвичайні, суспільні біди; тривалістю (коротко-, середньо-, довготривалі). Наголошено на важливості рівня знань, умінь і навичок комп'ютерних технологій не тільки майбутніх фрахівців цивільного захисту, але постійному онов ленні й опануванні зазначених технологій науково-педагогічні працівники. Зазначено, що основою модернізації освітньої системи $\epsilon$ перегляд сучасних концепцій освіти та пошук нових перспективних технологій. Доведено, що упровадження інсрорматизації освіти варто розпочинати з розробки та створення змісту, методів і стандартів різнорівневої освіти; інформаційної інфрраструктури закладу освіти; інформаційно-освітнього простору; системи підготовки педагогів до діяльності в нинішніх інфрормаційних умовах. Ключові слова: інсрормаційно-комунікаційні технології, фрахівець у сорері цивільного захисту, інформація, техногенні та природні катастрофи, професійна підготовка.
\end{abstract}

The article highlights the importance of the use of information technology by future civil protection specialists during their activities.

The future civil protection specialist is required to have the following competence such as foreign language skills, computer literacy, prompt resolution of professional responsibilities, flexible and innovative thinking, aptitude and ability for lifelong learning. Therefore, the use of modern information and communication technologies in the educational system of training and education of personnel for the SES of Ukraine is one of the priority directions of training and development of the future civil protection specialist. Civil protection specialists are often forced to act under uncertainty and lack of time. Therefore, the active involvement of relevant services, involvement of different forces and means, and their interaction, is urgently needed. The classification of the emergency situations are the following: causes of occurrence (natural, man-made, anthropogenic, mixed) is presented; complexity and severity of consequences (crisis, catastrophic, emergency, social disasters; duration (short-, medium-, long-term).

Emphasis is placed on the importance of the level of knowledge, skills and competencies of computer technologies not only for future civil protection specialists, but for the continuous updating and mastering of these technologies by scientific staff. It is noted that the basis of modernization of the educational system is the revision of modern concepts of education and the search for new technologies. It is proved that the introduction of educational informatization should start with the development and writing of content, methods and standards of level education; information infrastructure of the educational establishments; information and educational space; tutor training systems for activities in the current information environment.

Key words: information and communication technologies, civil protection specialist, information, man-made and natural disasters, professional training.
Постановка проблеми. Побудова суспільства, в якому знаряддям соціального розвитку держави слугуватимуть інфрормаційні технології - пріоритет України. Основною ознакою постіндустріального суспільства, тісно пов'язаною зі змінами в розподілі занять (збільшення кількості інтелігенції, фрахівців і «технічного класу»), $\epsilon$ перехід від виробництва речей до виробництва послуг. На відміну від індустріального суспільства - організації машин і людей для виробництва речей, основа постіндустріального суспільства - теоретичні знання. Новітнє суспільство інформаційних технологій, «на відміну від попе- редніх, більш зацікавлене у тому, щоб його громадяни були здатні самостійно, активно діяти, приймати рішення, гнучко реагувати на нові зміни умов життя» [8, с. 4]. Тож, основа модернізації освітньої системи - передусім у перегляді сучасних концепцій освіти й пошуку нових перспективних технологій.

Комп'ютеризація всіх галузей діяльності людини «виступає сьогодні і як найважливіше завдання суспільства, і як імператив соціального розвитку. Без вирішення цього завдання неможливі гуманістичні перетворення й економічний розвиток суспільства» [6, с. 301]. 
У світі, де царює конкуренція, від майбутнього фрахівця цивільного захисту вимагається: «грамотний» рівень володіння іноземною мовою, комп'ютерна грамотність, оперативне рішення проблем під час виконання професійних обов'язків, гнучке та інноваційне мислення, схильність і здібність до безперервної освіти. Тому використання сучасних інформаційно-комунікаційних технологій в освітній системі навчання та виховання кадрів для ДСНС України є одним із пріоритетних напрямів підготовки та розвитку майбутнього фахівця цивільного захисту.

Аналіз останніх досліджень і публікацій. Інформатизацію освіти й теоретичні основи застосування ІКТ у навчальному процесі закладів вищої освіти досліджували В. Биков, Б. Гершунський, М. Жалдак, В. Клочко, А. Коломієць, О. Співаковський, Є. Полат, Л. Шевченко та ін. Системний підхід у дослідженні педагогічних явищ розглядали Т. Ільїна, В. Краєвський, І. Підласий, В. Сластьонін, Т. Тализіна та ін. Теоретичними й методичними основами формування готовності до роботи за екстремальних умов займалися науковці Л. Кандибович, В. Пономаренко, В. Пліско, Я. Повзик, О. Самонов та ін. Питання єдності педагогічного процесу аналізували В. Бондар, І. Лернер, В. Луговий, Ю. Мальований та ін. Проблеми підготовки фрахівців цивільного захисту Державної служби надзвичайних ситуацій України аналізували О. Бикова, М. Варій, О. Євсюков, М. Коваль, М. Кусій, О. Повстин, П. Образцов, О. Тімченко, Т. Ткаченко.

Проте розвідки, які стосуються передавання інорормації сучасними засобами та комп'ютерними програмами у разі виникнення НС (надзвичайної ситуації) в українській педагогічній науці нечисленними, що зумовило вибір теми дослідження.

Метою запропонованої розвідки є дослідження важливості застосування інфрормаційних технологій майбутніми фахівцями цивільного захисту у профресійній діяльності.

Виклад основного матеріалу. Зі стрімким розвитком математичного моделювання й комп'ютерної графріки з'являються можливості для синтезу, відео, аудіо засобів інформування, а завдяки творчій уяві та інтуїції фрахівець цивільного захисту може поринути у віртуальну реальність, змодельовану комп'ютером.

Завдяки комп'ютерним технологіям вдається виконати одне 3 найважливіших освітніх завдань - налагодження взаємозв'язку викладача зі студентом, діалогу між репрезентантом нових знань і їхнього сприйняття суб'єктом, широкий вибір досліджуваного матеріалу тощо.

Проблему комп'ютеризації освіти вирішують на межі таких наук, як інформатика, педагогіка, психологія, математика тощо. Для того, аби у майбутніх фрахівців цивільного захисту швидше зростав рівень знань, умінь та навичок комп'ютерних техно- логій, науково-педагогічні працівники мають якнайоперативніше самі опанувати зазначені технології.

Комп'ютерні науки $€$ міжгалузевим досліднотехнологічним напрямом бакалаврської підготовки для інноваційної роботи з розробки теоретичних засад та інструментальних програмних засобів реалізації завдань розроблення, інтелектуалізації, інтеграції, автоматизації й управління складними розподіленими системами, мережами, організаціями, технологічними, соціальними й бізнес-процесами. Комп'ютерні науки входять або в технічні, або в математичні науки.

Комп'ютерні науки й інструментальні засоби застосовують, створюючи теоретичні й прикладні основи розробки, супроводження, інтелектуалізації й інтеграції різних інфрормаційних систем і технологій, передусім систем моніторингу, діагностики й управління виробничими, соціальними та економічними процесами, робото-технічних комплексів, розподілених інтелектуальних систем тощо.

Як навчальна дисципліна, інорормаційні технології - це сукупність взаємопов'язаних, наукових, технічних, комп'ютерних дисциплін для вивчення методів раціональної організації праці фрахівців, які опрацьовують та зберігають інфрормацію, методів організації взаємодії рятувальників із технічним обладнанням пов'язаних із їхньою діяльністю.

Концепція державної політики інорорматизації термін «інфрорматизація» подає як «інтелектуальний і матеріальний процес, що полягає у створенні глобальної інфраструктури сучасних засобів зберігання, опрацювання, передавання і подання інфрормації, яка стає стратегічним ресурсом суспільства» [5, с. 32]. Бо розвиток мережевих технології, баз даних онлайн, комп'ютерного моделювання, застосування Інтернет-ресурсів, інтелектуальних інорормаційних систем у робототехніці - основні тенденції розвитку інформаційних технологій.

Тому порівняємо інформаційні й комп'ютерні технології. Зазначені терміни виникли від назв конкретних технічних засобів, що реалізують ту чи іншу технологію: комп'ютер, комунікації тощо.

Дослідник В. Глушков зазначає, що «інсрормаційні технології - людино-машинна технологія накопичення, оброблення та передавання інфрормації» [1, с. 10-24]. Інакше кажучи, це сукупність процесів руху й переробки інорормації, а також їх описи. Об'єкт переробки й руху - це дані, інорормація. Схеми технологічною процесу (маршруту) і сценарії (інструкції) процесів переробки інформації - складові частини цих описів.

Суміжними до поняття «інформаційні технології» $€$ терміни «інорормаційно-комунікаційні технології» [3, с. 3-13]; «нові інфрормаційні технології» [7, с. 32-38]; «інфрормаційно-телекомунікаційні технології» [2, с. 61-68] тощо.

Інформаційні технології - це сукупність методів, виробничих процесів і програмно-технічних серед- 
овищ для пошуку, обробки та зберігання інформації; «сукупність методів, засобів і прийомів, що використовуються для реалізації та забезпечення інформаційних процесів у різних галузях людської діяльності» [4, с. 3].

Через комп'ютерну інтелектуальну обробку знання людина втратила монополію на продукування знання. Тому основне для майбутнього фрахівця - ухвалювати рішення та застосовувати знання. Комп'ютерна грамотність сьогодні - складова частина культури й ресурс суспільного розвитку, якщо вона репрезентована в доступних для засвоєння й подальшого застосування моделях. Продукування нового наукового знання сьогодні дуже поширене, втім репрезентація його в доступних для освоєння й інтерпретацій комп'ютерних моделях істотно відстає. Завдяки експертним системам, побудованим на порталах, можливе вдосконалення знань, перетворення неповних, непослідовних знань на точніші й зрозуміліші. Отож, комп'ютер спроможний продукувати знання.

Важливим для дослідників інфрормаційним ресурсом у рамках спільного проекту INTAS стало розроблення Бібліотеки електронних журналів. Провідній організації з виконання національної й галузевої програм інфрорматизації Інституту програмних систем - також належить чималий досвід у створенні конкурентоздатного програмного забезпечення.

Становлення у 80-х pp. XIX ст. суспільство, яке послуговується знаннями, зумовило потребу в оптимізації освоєння знання, а відтак появу інженерії знань - інструментарію класифрікації, структурування знання, розроблення та вдосконалення мови, репрезентації його в інтелектуальних системах, навчальних моделей знання й комп'ютерної технології освіти.

Поняття «інформаційна освіта» застосовують для позначення освіти фахівця в інформатиці, інсрормаційних процесах, технологіях. Упровадження інсрорматизації освіти варто розпочинати з розробки та створення змісту, методів і стандартів різнорівневої й поліпрофільної інфрормаційної освіти; інфрормаційної інфрраструктури закладу освіти; інфоомаційно-освітнього простору; системи підготовки педагогів до діяльності в нинішніх інсрормаційних умовах.

Завдяки зазначеному вдасться досягнути основної цілі інформаційної освіти - формування в особистості рівня інсрормаційної зрілості, аби досягти самостійності в різних галузях.

Тут варто виокремити важливість метанаук комплексних інтеграційних галузей знання. Ідеться про методо- й інфрормологію.

Інформологія слугує наукою про інфрормацію та ії сутність, структуру й діяльність як одної з категорій світогляду із часом і простором.

Інсормологічне обґрунтування інсрормаційнотехнологічної підготовки $€$ основою конструювання інтеграційно-інформаційного бачення світу в людській свідомості, створення системи, що дає змогу людині почуватися успішним членом інфрормаційного суспільства. Щодо соціальної галузі, зокрема освітньої, ідеологія інфрормологічного підходу інтегрує систему поглядів та ідей, котрі визначають розвиток фрахівця активного, всебічно розвиненого учасника комп'ютеризованого суспільства, який вправно оперує прийомами інтелектуальної діяльності, адекватними умовам інсрормаційно-комунікативної дійсності.

За зазначених умов звичні бачення інформатики не обмежуються способами обчислювальної обробки інформації й розробленням питань технічного й програмного забезпечення. Завдяки підходу інфрормології поглиблюється і розуміння предмета інорорматики, і реальне фрормування інфрормаційних грамотності, культури, мислення. Формування власне інформологічного підходу полягає в тому, що «інформацію» почали розглядати як гносеологічну категорію і метазасіб діяльності поряд з умовно й безумовно необхідними засобами діяльності.

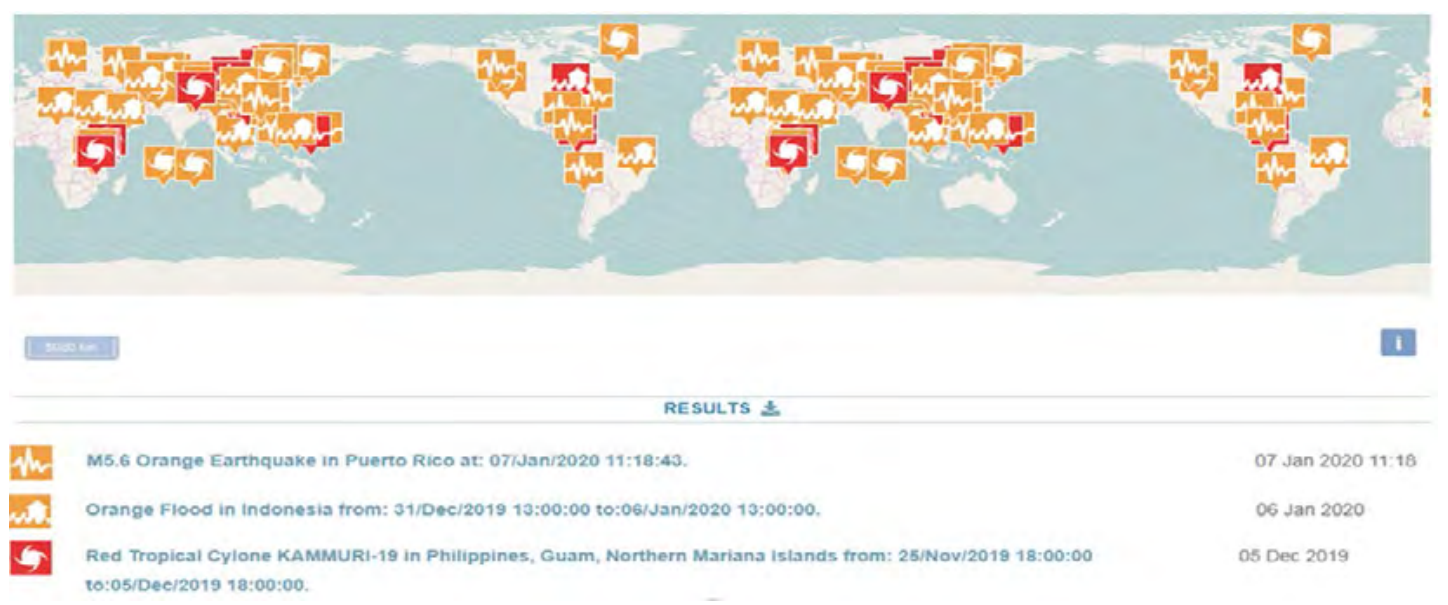

Рис. 1. Карта координації сигналів-катастрофр 
Філософри й культурологи тлумачать інорормаційну культуру як галузь культури, пов'язану з фрункціонуванням інфрормації в суспільстві й фрормуванням інфрормаційних рис індивіда, як аксіологічну інформаційну діяльність, зумовлену культурними цінностями.

Згідно 3 інфрормологічною парадигмою, культура $€$ інформаційною пам'яттю людства, наука системою збирання, переробки, зберігання й поширення інформації, конструювання інфрормаційних моделей, освіта - задоволення потреби в пізнанні, що задовольняє потреби студентів у інфрормації [9, с. 4-19].

Оскільки, антропогенні порушення й техногенне перевантаження територій у нинішніх умовах стрімкого розвитку багатьох країн зумовлюють часті виникнення різних надзвичайних ситуацій: масштабних повеней і пожеж, землетрусів і ураганів, промислових і транспортних катастроф. Тому, внаслідок надзвичайних ситуацій техногенного та природного характеру щодня гине чимало людей, а також страждають практично всі сорери людської діяльності: економічна, політична, культурна. Не менш жахливий наслідок - негативний вплив на психоемоційний стан людини.

Фахівці зі сорери цивільного захисту часто змушені діяти в умовах невизначеності й браку часу. Тож тут украй необхідна активна участь відповідних служб, залучення різних сил і засобів, їх взаємодія.

У зв'язку з вище поданим у Європі існує організація (Global Disaster Alert Coordination System / GDACS) Глобальна комп'ютерна система координації сигналів про катастрофри, яка забезпечує подачу й обмін інфрормацією, стратегію подальшого розвитку послуг на першій фразі після великих катастроф у світі. До консультативної групи GDACS керівники штабів, науковці, експерти-географи, веб-майстри та фахівці зі сфери цивільного захисту [10].

У зв'язку із зазначеним, вимоги до рівня фрахової, зокрема психологічної підготовки фрахівців, які в екстремальних умовах повинні приймати управлінські рішення й ліквідовувати наслідки надзвичайних ситуацій, неабияк зростають.

Тому, на сьогодні основні вимоги до навчального процесу майбутніх фрахівців цивільного захисту полягають у профресійній підготовці висококваліфрікованого фахівця, який вільно уміє застосовувати інформаційні технології, володіє хоча б однією іноземною мовою, готового до подолання будь-якої небезпечної ситуації, з належними етичними якостями поведінки в екстремальних ситуаціях, відповідального, мужнього, стресостійкого тощо.

Незвичайні, важкі у фрізичному й психологічному аспектах, часто пов'язані з ризиком для життя тощо - це екстремальні ситуації. Їх розрізняють за важкістю, ступенем і характером загрози, ймовірними наслідками.
Надзвичайні ситуації класифрікують за: причинами виникнення (стихійні, техногенні, антропогенні, змішані); комплексністю й важкістю наслідків (кризові, катастрофічні, надзвичайні, суспільні біди; тривалістю (коротко-, середньо-, довготривалі).

Для належної організації роботи та екстремальної підготовки фрахівців пожежно-рятувальних підрозділів НС поділяють на п'ять категорій:

- V категорія характерна ймовірністю загрози для життя фрахівців, що становить 0-0,2. Умови й обставини не складні, відносно безпечні й без психологічного напруження;

IV категорія характерна можливою загрозою для життя фрахівців, що становить 0,21-0,4. Умови й обставини можуть ускладнювати діяльність фрахівців з НС та характерні низькими ймовірністю загрози для їхнього життя й психічним напруженням;

III категорія характерна можливістю загрози для життя фрахівців, що становить 0,41-0,6. Умови й обставини непрості й можуть спричинити травми, каліцтва і навіть смерть, психічне напруження помірне;

II категорія характерна можливістю загрози для життя фрахівців, що становить 0,61-0,8. Умови й обставини високого рівня складності, внутрішнє напруження високе;

I категорія характерна можливістю загрози для життя фрахівців, що становить 0,81-1. Умови й обставини максимально високого рівня складності, можливі переживання, напруження й перенапруження.

Тому, у навчальному процесі майбутніх фрахівців цивільного захисту є надзвичайно важливими практичні вміння основ інфрормаційної обробки та подання інформації задля своєчасного порятунку населення та забезпечення заходів для ліквідації наслідків різних стихійних лих.

Висновки. Таким чином, серед різноманітних педагогічних застосувань нових інорормаційних технологій особливо слід наголосити на важливості розробки та використанні програмних засобів навчально-фрахового призначення, у яких відображатимуться окремі предметні галузі природо-технічних дисциплін для подальшого практичного їх застосування у майбутній професійній діяльності.

\section{БІБЛІОГРАФІЧНИЙ СПИСОК:}

1. Глушков И.М. Мышление и кибернетика. Вопросы фрилософии. 1963. № 1. С. 10-24.

2. Гуревич Р.С. Інформаційно-телекомунікаційні технології у підготовці майбутнього фахівця. Неперервна професійна освіта: теорія і практика. 2002. Вип. 4 (8). С. 61-68.

3. Жалдак M.І. Педагогічний потенціал комп'ютерно-орієнтованих систем навчання математики. Комп'ютерно-орієнтовані системи навчання : збірник наукових праць. Київ : НПУ ім. М.П. Драгоманова. 2003. Вип. 5. С. 3-13. 
4. Жалдак М.І., Рамський Ю.С. До концепції шкільної освіти 3 інформатики .Комп'ютерноорієнтовані системи навчання : збірник наукових праць. Київ : НПУ ім. М.П.Драгоманова. 2001. Вип. 3. С. 3-7.

5. Концепція державної політики інформатизації. Основні напрями національної програми інсоорматизації України. 1994. 32 с.

6. Лавриненко В.Н. Философия. Юристъ, 2004. 375 C.

7. Новиков С.П. Применение новых инсормационных технологий в образовательном процессе. Педагогика. 2003. № 9. С. 32-38.
8. Савченко О.О. Західна парадигма освіти на початку XXI століття (соціально-філософський аналіз) : авторефр. дис. ... канд. фрілос. наук : 09.00.03. Харків. 2008. 23 C.

9. Тумалева Е.А. Становление профессиональной компетентности в информационно-технологической подготовке специалиста в области образования. Известия Российского государственного педагогического университета им. А.И. Герцена. 2004. T. 4. № 9. C. 4-19.

10. Global Disaster Alert Coordination System (GDACS) URL: https://www.gdacs.org/Alerts/default. aspx. 